\title{
O DIREITO À VIDA VERSUSO DIREITO À PRIVACIDADE NOS CONTRATOS DE DOAÇÃO DE MATERIAL GENÉTICO ${ }^{1}$
}

\begin{abstract}
Janaína Reckziegel
Doutora em Direitos Fundamentais e Novos Direitos pela Universidade Estácio de Sá - RJ. Mestre em Direito Público. Especialista em "Mercado de trabalho e exercício do magistério em preparação para a Magistratura" e em "Educação e docência no ensino superior". Graduada em Ciências Jurídicas e Sociais pela Universidade do Oeste de Santa Catarina. Advogada, Professora Universitária e Pesquisadora do Programa de Pós-Graduação em Direito da Universidade do Oeste de Santa Catarina - UNOESC de Chapecó - SC. Editora de Seção da Revista Espaço Jurídico Journal of Law da Editora UNOESC (Qualis A2). E-mail: janaina.reck@gmail.com. Endereço de acesso ao banco de currículos do sistema lattes: <http://lattes.cnpq.br/7597547217990217>.
\end{abstract}

\section{Jhonatan Felipe Laurindo Gomes Duarte}

Doutorando em Direito pela Universidad Nacional de Córdoba - AR. Mestre em Direito pelo Programa de Pós-Graduação em Direito da Universidade do Oeste de Santa Catarina - UNOESC. Graduado em Direito pela Faculdade de Ciências Sociais Aplicadas de Cascavel - UNIVEL. Advogado. Professor Universitário e Membro do Centro de Pesquisa e Extensão da Faculdade de Colíder - FACIDER de Colíder - Mato Grosso. E-mail: jhonatann_duarte@hotmail.com. Endereço de acesso ao banco de currículos do sistema lattes: <http://lattes.cnpq.br/6183369838762264>.

Resumo: O presente artigo tem como objetivo a análise do direito à vida em face do direito à privacidade, especialmente em sua espécie atinente à genética humana, em torno dos contratos de doação de material genético existentes nas práticas de Reprodução Humana Assistida. Para tanto, o corrente estudo se debruça sobre a problemática da colisão de direitos fundamentais, estabelecendo o seu significado e práticas de solução, apelando principalmente para a técnica da ponderação criada por Robert Alexy. Passada a análise do conflito jusfundamental, estipula-se uma solução possível para o conflito apontado, recorrendo às técnicas de resolução apontadas até então, determinando-se a prevalência do direito à vida, desde que respeitada uma série de paradigmas de condução da ponderação no caso em tela. A pesquisa ora conduzida é de ordem eminentemente bibliográfica, com influência de julgados de Tribunais Constitucionais de países como Alemanha e Brasil, além de basear-se na clássica teoria de direitos fundamentais existentes no direito continental.

Palavras-chave: Colisão de direitos fundamentais. Direito à vida. Direito à privacidade. Reprodução Humana Assistida. Doação de material genético.

Sumário: Introdução - 1 A problemática da colisão de direitos fundamentais - 2 Teorias da solução de conflito entre direitos fundamentais: a ponderação em Alexy - $\mathbf{3}$ Vida e intimidade (genética): um conflito passível de ponderação na Reprodução Humana Assistida? - 4 Considerações finais - Referências

1 O presente trabalho é resultado do Grupo de Pesquisa Direitos Fundamentais Civis/Sociais do Programa de Mestrado em Direito da Universidade do Oeste de Santa Catarina - UNOESC. 


\section{Introdução}

A Reprodução Humana Assistida, como já esperado, trouxe consigo uma série de vetores bioéticos, que emergem numa série de conflitos jurídicos já detalhados pela literatura especializada. A possibilidade de controlar a própria reprodução da espécie é matéria controvertida por razões que extrapolam a religião e o mero senso comum arraigado: é questão ética de observância elementar.

O problema ético - e jurídico - da Reprodução Humana Assistida, como não poderia deixar de ser, vai ao imediato encontro da teoria já solidificada dos direitos fundamentais. Garantias constitucionais positivadas ou naturais agora passam ao centro das atenções graças à postura judicial esperada em detrimento das inúmeras possibilidades que o caso concreto apresenta sem cessar.

A horizontalização dos direitos fundamentais - teoria que passa a ganhar força após o advento da Segunda Guerra Mundial - cuida de estabelecer a série de nuances éticas e jurídicas que a Reprodução Humana Assistida avoca. A inafastável necessidade de respeito aos direitos fundamentais, agora no plano entre particulares, traz uma série de possibilidades jurídicas sobre as quais o presente estudo repousa.

Tendo-se de um lado a vida e doutro a privacidade, ambas as garantias jusfundamentais não funcionam como compartimentos estanques e impassiveis de ponderação e apreciação. Como direitos fundamentais que são, podem colidir a qualquer instante, invocando a imediata aplicação das técnicas de solução de tais conflitos, onde se destaca a ponderação de Alexy.

Assim sendo, o presente estudo se inicia pela análise dos conflitos de direitos fundamentais, debruçando-se sobre seus elementos informadores e respectivos conceitos, passando, num segundo momento, à análise das técnicas de solução de colisão entre as garantias constitucionais apontadas. O tópico final, por sua vez, é dedicado inteiramente ao hard case que enseja a realização desta pesquisa: vida e privacidade enquanto direitos fundamentais colidentes nos contratos de doação de material genético e os possíveis desdobramentos de tal paradoxo constitucional, com a constante visualização de todos os seus elementos informadores.

\section{A problemática da colisão de direitos fundamentais}

Os direitos fundamentais, sob o espeque jurídico-dogmático, adquirem importância sob o plano de sua violação. Não há quem pense no livre exercício jusfundamental quando na plena titularidade destas mesmas garantias, mas inolvidáveis são seus mecanismos de defesa num quadro de flagrante intransigência 
constitucional. Assim, é acertado expor que "[...] os direitos fundamentais tornamse relevantes somente quando ocorre uma intervenção em seu livre exercício" (DIMOULIS; MARTINS, 2014, p. 129).

Para Dimoulis e Martins (2014, p. 129), “o estudo dos direitos fundamentais carece de utilidade prática e de profundidade teórica enquanto se limita a reproduzir e comentar o conteúdo garantido na Constituição". Só há relevância no aprofundamento teórico dos direitos fundamentais, de acordo com os autores apontados, quando se "[...] formula e responde a pergunta: Sob quais condições, em quais situações e quem pode restringir um direito fundamental de forma lícita?" (DIMOULIS; MARTINS, p. 130).

Duas condições são necessárias para a visualização da importância do estudo dos direitos fundamentais: "a presença de um óbice em relação ao exercício do direito fundamental e a provocação desse óbice por norma hierarquicamente inferior à Constituição" (DIMOULIS; MARTINS, 2014, p. 130), sendo que tal óbice pode ser de origem normativa ou mero ato administrativo.

Ressalva que merece ser apontada é quanto aos tipos de conflitos que emergem do caso concreto. Tal embate entre direitos fundamentais pode ser de duas ordens: direto ou de interesse geral. O primeiro caso exsurge entre o liame conflituoso direto entre dois direitos fundamentais - liberdade de imprensa e intimidade; vida e privacidade; etc. - e o segundo advém do embate entre uma parcela divisível ou não de indivíduos e um sujeito de direitos, como proteção ambiental versus atividade empresarial, segurança pública versus manifestações violentas, entre outras (DIMOULIS; MARTINS, 2014).

Um conceito que merece ser apontado é acerca da instrumentalidade normativa dos direitos fundamentais. Iniciada pela teoria alemã e assentada no Brasil graças à obra de Steinmetz (2001) e Sarlet (2009), tal instrumentalidade pauta “[...] o exame de constitucionalidade específico e a argumentação a ele inerente, facilitando a tarefa de identificar com a maior precisão possível a extensão da violação de quais normas constitucionais" (DIMOULIS; MARTINS, 2014, p. 132).

São conceitos englobados por tal instrumentalidade: "área de regulamentação, área de proteção objetiva [status jurídico tutelado] e área de proteção subjetiva (titular) compõem o tipo normativo de um direito fundamental (Grundrechtstatbestand)" (DIMOULIS; MARTINS, 2014, p. 132).

Archanjo lança luzes acerca da fundamentalidade dos direitos fundamentais. Para a autora, a questão central antes de se desdobrar no próprio embate jusfundamental é "por que os direitos fundamentais são ditos fundamentais" (ARCHANJO, 2008, p. 155). Caminho que se aponta é em direção da teoria de Alexy, onde direitos fundamentais podem ser formal ou materialmente constitucionais, sendo os primeiros vislumbráveis como direitos dentro da moldura textual constitucional 
expressa, e os últimos como advindos de documentos internacionais ou do próprio sentimento de dignidade jusnaturalista, remanescendo o problema quanto a quais direitos teriam expressividade jusfundamental o bastante para sustentar sua própria qualidade de direito fundamental.

Importante distinção a ser traçada é quanto à concorrência e colisão de direitos fundamentais, vez que “[...] desempenham papéis dogmáticos a serem enfrentados em momentos diferentes do exame de constitucionalidade e, portanto, muito distintos entre si" (DIMOULIS; MARTINS, 2014, p. 169). A colisão de tais direitos é analisada unicamente no instante da possível justificação de eventual intervenção do Estado, visto que uma garantia fundamental de titular de direito pode estar cerceando o livre exercício de direito fundamental atingido pela própria ação ou omissão estatal.

A concorrência de garantias jusfundamentais possui, no exame de constitucionalidade, caráter prejudicial, buscando a definição do parâmetro de avaliação. “Isso ocorre quando houver concorrência entre mais de um parâmetro e, assim, o titular puder se valer de mais de um direito fundamental contra uma mesma intervenção estatal" (DIMOULIS; MARTINS, 2014, p. 169).

Retomando a análise apartada da colisão de direitos fundamentais, aponta Archanjo (2008, p. 159) que “o regime democrático por si só pressupõe esse pluralismo de interesses, consubstanciado em um texto constitucional. Essa diversidade, oriunda de múltiplas teorias e concepções de Estado e de sociedade [...] leva, inevitavelmente, ao surgimento de conflitos, de colisões de direitos".

A colisão de direitos fundamentais é exposta por Steinmetz (2001, p. 139) “[...] quando, in concreto, o exercício de um direito fundamental por um titular obstaculiza, afeta ou restringe o exercício de um direito fundamental de um outro titular", sendo que Dimoulis e Martins (2014) complementam tal noção apontando para o fato de que é dever jurisprudencial e doutrinário a fixação de limites que possibilitem a convivência harmônica dos direitos colidentes, independentemente da dificuldade para a obtenção da solução.

Azevedo e Gambiatti (2008) traçam importante paralelo na teoria da colisão dos direitos fundamentais, com fulcro no pensamento de Bobbio. Para os autores, por serem os direitos fundamentais um contraponto ao abuso de poder que se busca combater, não haveria que se falar em teoria tradicional dos direitos fundamentais colidentes.

Assim, "se há algum conflito, não é entre direitos, mas conflitos resultantes da própria relação de poder que existe na sociedade. Nada mais é que a tensão existente no conflito entre aquele que tem fome, com aquele que detém vasto capital, ou seja, uma tensão social” (AZEVEDO; GAMBIATTI, 2012, p. 85). 
A relação entre Estado e indivíduo é determinante para o detalhamento da teoria de direitos fundamentais adotada, vez que o modelo prestacionista estatal, acionado em qualquer necessidade de socorro de garantias fundamentais deve(ria) ser chamado para que "[...] intervenha e forneça condições paritárias (ao menos mais próximas) aos indivíduos" (AZEVEDO; GAMBIATTI, 2012, p. 85).

Salomão e Marques (2014) estipulam o critério de intervenção estatal na defesa de garantias fundamentais em torno das relações sociais de poder - que no caso dos direitos fundamentais se expressam mormente no campo político apelando ao fato de que a instância hábil a dirimir tais conflitos de participação conflituosa ou minoritária é inegavelmente o Poder Judiciário.

Nos quadros de Reprodução Humana Assistida, o hard case sobre o qual o corrente estudo se debruça é num quadro de embate entre o direito à vida do indivíduo gerado pelas técnicas reprodutivas e à intimidade do doador de material gênico. Desta forma, o conflito entre os direitos fundamentais apontados - vida e intimidade (genética) - sedimentam toda a discussão que ora se propõe.

Ahmad (2009) vislumbra que a já citada ausência de regulamentação de determinadas práticas de Reprodução Humana Assistida não significa a omissão final dos poderes republicanos. Pelo contrário, vê a autora o fato da eventual colisão de direitos fundamentais que o aporte reprodutivo assistido traz à tona ser justificativa razoável para a invocação de teorias resolutivas de tais direitos colidentes. Desta feita, a ponderação e outros meios de solução de embates jusfundamentais revelam "[...] uma clara prevalência valorativa dos interesses tutelados pela Constituição Federal, de forma a harmonizá-los nas circunstâncias da situação concreta, evitando o sacrifício completo de uns em detrimento dos outros" (AHMAD, 2009, p. 123).

É exigivel, assim, a existência de um caso concreto para que a teoria constitucional se debruce. Não é possível, diante de tal contexto lacunoso de regulamentação legislativa, almejar a invocação da teoria da ponderação dos direitos fundamentais no cenário da Reprodução Humana Assistida sem a efetiva existência de um caso factível de direitos fundamentais em risco. É apenas através do risco tangivel que a teoria adquire importância, consoante a cristalina opção da Constituição pelo justo equilíbrio em todas as suas vertentes e hipóteses, conforme se faz ver nos tópicos a seguir.

\section{Teorias da solução de conflito entre direitos fundamentais: a ponderação em Alexy}

A análise da colisão de direitos fundamentais envolve, de acordo com Gorzoni, a necessária distinção entre princípios e regras eventualmente colidentes. Para a 
autora, incorporando o pensamento de Alexy, um conflito de regras só pode ser resolvido apelando à criação de exceção de uma delas ou por meio de declaração de invalidade, também de uma delas. Por sua vez, um conflito entre princípios é necessariamente resolvido através da cessão de um perante o outro. "Entretanto, isso não significa que exista a declaração de invalidade de um princípio. Diante de certas circunstâncias do caso concreto, um princípio precede o outro. A dimensão a ser avaliada não é de validade, mas sim de peso de cada princípio" (GORZONI, 2009, p. 274).

Estando os direitos fundamentais ao lado dos mandamentos de otimização judicial que são os princípios, tal proximidade “[...] implica a máxima de proporcionalidade, com suas três máximas parciais - adequação, necessidade e proporcionalidade em sentido estrito" (GORZONI, 2009, p. 274). Tal noção de proporcionalidade encontra sua origem histórica no Tribunal Constitucional Federal alemão, que chegou até mesmo a expor o fato de que "[...] embora não positivada no texto constitucional, possui [a proporcionalidade] status constitucional" (DIMOULIS; MARTINS, 2014, p. 179).

Apelando à consistência filosófica da origem da proporcionalidade na jurisprudência, apontam Dimoulis e Martins (2014, p. 181) que "muito tempo e esforço foram despendidos com a insistência na tese de que o texto constitucional relativo aos direitos fundamentais ofereceria um sistema de valores que deveriam ser respeitados e que permitiriam hierarquizar e quantificar os direitos fundamentais", sendo tal procedimento com base no valor abstrato ou demonstrado no caso em tela. Tal tese foi diretamente responsável pelo fortalecimento da proporcionalidade em sentido estrito, que mais tarde passou a predominar a teoria do conflito de direitos fundamentais.

Briancini (2007) explana acerca do fato de que a ponderação engloba a própria proporcionalidade, que, por sua vez, traz seus respectivos subprincípios a seguir discorridos. Para a autora, o início da proporcionalidade enquanto mecanismo de solução de conflitos jusfundamentais no plano fático surge na transição do Estado de Polícia da monarquia para o Estado de Direito, sendo que sua primeira aparição foi no Direito Administrativo enquanto critério de proporcionalidade das penas e de evolução da legalidade.

O cenário de efetiva aplicabilidade da proporcionalidade nos direitos fundamentais veio após a Segunda Guerra Mundial. O núcleo essencial dos direitos fundamentais - Wesensgehaltsgarantie - passou a ser protegido em virtude dos desmandos da legalidade por si só, prova cabal de que a ausência de proteção de direitos fundamentais em espécie era chancela para sua violação (BRIANCINI, 2007).

Previamente aos desdobramentos da teoria de Alexy, Mastrodi (2014) enfatiza o fato de que não coube ao jurista alemão criar a teoria da proporcionalidade 
dos direitos fundamentais, mas sim conferir critérios objetivos de apuração da aplicabilidade - ou não - de tal diretiva. O grande mérito de Alexy foi, afinal, a possibilidade de prevalência de direitos fundamentais sociais sobre os individuais, hipótese aparentemente impossível até então.

Schlink traça o princípio da proporcionalidade como traço característico da transição do Estado de Direito clássico do século XIX para o contemporâneo, Estado democrático, constitucional e de prestações positivas, com a transmutação da exigência de reserva legal em “[...] exigência da reserva de lei proporcional” (DIMOULIS; MARTINS, 2014, p. 180). Ponto de transição importante foi a tomada pela questão da proporcionalidade pelo viés judicial, não meramente legislativo, deixando ela de ser vista como critério de equilíbrio normativo e passando a ser verdadeira tarefa do intérprete.

Campos aponta o ano de 1993 como o marco jurisprudencial de reconhecimento do princípio da proporcionalidade no ordenamento constitucional brasileiro. Foi em tal data que o STF finalmente reconheceu a existência e aplicabilidade de tal axioma. Sem prejuízo do exposto, o princípio da proporcionalidade em seu âmago meramente semântico-gramatical pode ser traduzido como se ordenasse “[...] que a relação entre o fim que se busca e o meio utilizado deva ser proporcional, nãoexcessiva. Deve haver uma relação adequada entre eles" (CAMPOS, 2004, p. 27).

O princípio da proporcionalidade hoje se encontra sob o jugo do Judiciário pelo fato de que "as demandas sociais e as complexidades dos problemas aumentaram demasiadamente, alcançando um grau de detalhamento e especialização que o legislador não conseguiu prever e, tampouco, acompanhar e dar uma resposta imediata e adequada" (RECKZIEGEL; FREITAS, 2014, p. 697). Indo ao encontro do exposto, também há de se citar, ainda na esteia de Reckziegel e Freitas (2014), o fato de que, com o advento da Teoria Pura do Direito, a busca pelo legislador da tratativa de situações hipotéticas fundadas na norma jurídica superior - a Grundnorm - o deixou (in)conscientemente alheio às complexidades de assuntos ainda no campo da hipótese.

A Teoria da Ponderação, gênero da proporcionalidade que até então se expõe, é sintetizada por Campos (2004, p. 28) na medida em que “[...] quando se tem direitos fundamentais em conflito perante um caso concreto, é necessário que sofram eles uma ponderação em razão do bem ou do valor que se pretende tutelar naquele caso específico. É necessária a constante busca da harmonia entre direitos [...]", de maneira que se propõe a ponderação a buscar tal fim.

No caso de colisão jusfundamental, a solução apontada por Reckziegel (2006, p. 88) “[...] consiste em, considerando as circunstâncias do caso, se estabelecer entre os princípios uma relação de procedência condicionada. Ou seja, no caso de colisão os princípios precisam ser 'pesados' para que um ceda ante o 
outro". Para a autora, tal relação de ponderação criada por Alexy surge em virtude da já apontada impossibilidade de se remover um princípio da ordem jurídica, bem como excepcioná-lo.

Retomando os subprincípios da proporcionalidade - necessidade, adequação e proporcionalidade em sentido estrito -, vê-se que o último “[...] é a ponderação determinante do grau de realizabilidade ou satisfação dos princípios no caso concreto, com relação às possibilidades jurídicas. Enquanto a máxima da necessidade e da adequação segue o caráter dos princípios como mandamentos de otimização em relação às possibilidades fáticas" (RECKZIEGEL, 2006, p. 90).

Campos, nesta mesma senda, sintetiza a interconexão entre os três subprincípios aludidos, apontando que o princípio da proporcionalidade - e, consequentemente, a ponderação - se concretiza “[...] através de um juízo de adequação da medida adotada [...]; através de uma reduzida interferência sobre direitos fundamentais individuais, limitando-se ao estritamente necessário para atingir a finalidade que a justifica; e, através de uma justa medida de ponderação de interesses ao caso concreto" (CAMPOS, 2004, p. 29).

Em síntese, é acertado mencionar que "[...] para Alexy, enquanto o conflito entre regras deve ser solucionado na dimensão da validade, a colisão entre princípios deve ser resolvida na dimensão do peso" (CUNHA JÚNIOR, 2012, p. 162, grifos do autor). Nas palavras do próprio Alexy (2008, p. 193) "as condições sob as quais um princípio tem precedência em face de outro constituem o suporte fático de uma regra que expressa a consequência jurídica do princípio que tem precedência".

Bessa traz à baila o fato da heterogeneidade de direitos fundamentais ser facilmente percebida, diante do conteúdo de carga valorativa aberta e variável conforme o caso concreto ou axiomas constitucionalmente protegidos. Assim, no caso de aparente conflito dessas complexas estruturas jurídicas, vê-se como primeiro passo lógico a mensuração do âmbito de proteção do direito fundamental, tratando-se "[...] de parcela da realidade que o constituinte houve por bem definir como objeto da proteção da garantia fundamental" (BESSA, 2005, p. 4).

Conforme explica o mesmo autor, a delimitação do âmbito de proteção do direito fundamental se deve ao fato de que a interpretação meramente literal do direito que se apresenta pode fazer confundir o intérprete, já que “[...] pode fazer crer protegida certa situação, que na verdade foge ao real âmbito de proteção deste direito" (BESSA, 2005, p. 4). Neste desiderato, a teoria liberal implica a constante defesa dos direitos fundamentais enquanto mecanismo de proteção do indivíduo em face do Estado, sendo esta a única premissa aparentemente inalterada de todo o silogismo jusfundamental.

Seria acertado expor, assim, que vencida a questão do efetivo campo de proteção do direito, muitos dos então conflitos se dissolveriam sob o espectro 
de conflitos aparentes de direitos, uma vez que "a colisão não ocorre, mas uma simples aparência de conflito de normas veiculadoras de direitos fundamentais, sanável pela fixação dos âmbitos de proteção de ambos, a fim de que não mais se interpenetrem"2 (BESSA, 2005, p. 6).

Caso ainda haja a possibilidade de se falar de conflito entre direitos fundamentais mesmo após tal delimitação de incidência e proteção, verifica-se verdadeira colisão de direitos fundamentais. Neste caso, pode tal colisão se subdividir entre colisões em sentido amplo e colisões em sentido estrito. As colisões em sentido amplo avocam o embate de garantia fundamental com outros valores protegidos pela Constituição. As colisões em sentido estrito, em que pesem também poderem ser divididas em inúmeras escalas, são comumente repartidas na ordem apontada por Bessa (2005, p. 7):

Dividem-se, inicialmente, em colisões entre direitos fundamentais idênticos e colisões entre direitos fundamentais diferentes. Dentre os primeiros, podemos pinçar: a) colisão de direitos fundamentais de defesa, quando dois indivíduos ou grupos reivindicam o mesmo direito de liberdade (reunião na mesma praça pública, por exemplo); b) colisão de direito fundamental de defesa com direito de proteção; c) colisão dos caracteres negativo e positivo de um mesmo direito (liberdade religiosa, por exemplo, que gera o direito a não ter religião); d) colisão entre o aspecto jurídico e o fático de um determinado direito (colisão comum no direito de igualdade).

Se os conflitos entre direitos fundamentais "[...] são idênticos aos conflitos entre princípios", faz sentido a percepção de que a primeira chancela para a correta mensuração acerca de se tratar ou não de conflito jusfundamental é justamente a aplicabilidade ou não do efetivo campo de proteção do direito, já que, "devidamente superada a fase de observância dos âmbitos de proteção dos direitos envolvidos, resta a constatação de que se formou uma autêntica colisão de direitos fundamentais" (BESSA, 2005, p. 7).

Bessa retoma a questão de que na tratativa para a resolução de conflitos entre direitos fundamentais, em que pese a inaplicabilidade de métodos hermenêuticos clássicos, é importante manter em vista o fato de que o direito eventualmente precedido por outro não deixará de fazer parte do ordenamento jurídico

2 Exemplo fornecido por Bessa (2005) é no sentido de divulgação de ideias racistas sob a suposta proteção do direito à liberdade de expressão. Para o autor, não se trataria de efetivo conflito entre a dignidade da pessoa humana e a liberdade citada, já que esta última não compreende a divulgação de um ideário que destoe da diretiva constitucional de valores. 
fundamental, mas apenas cederá espaço naquele caso concreto e em outros de igual facticidade. Em apertada síntese, "deve haver um sopesamento dos interesses envolvidos no caso controvertido, a fim de que seja fixado qual princípio deve ter prevalência sobre aquele outro que se põe em oposição aos seus preceitos. Trata-se, da aplicação de critérios de justiça prática" (BESSA, 2005, p. 8).

Ressaltando a falta de absolutismos principiológicos, Cunha Júnior destaca o fato de que o mesmo princípio - ou direito fundamental - que cedeu em situação anterior pode vir a ser prevalente em novo caso concreto. Assim, "tudo dependerá do sopesamento que deve ser feito entre os interesses ou bens jurídicos tutelados pelos princípios em colisão, para, avaliando as condições do caso concreto, aferir-se qual dos princípios em colisão tem maior peso [...]" (CUNHA JÚNIOR, 2012, p. 162, grifo do autor).

Circunstância final da ponderação é o fato de garantir uniformidade decisória e previsibilidade das consequências advindas nos conflitos de direitos, conferindo objetividade aos critérios ponderadores a fim de evitar a subjetividade. Os parâmetros da ponderação não são, contudo, rígidos ou imutáveis, sendo, sem verdade, flexíveis enquanto instrumentos de balizamento constitucional (BESSA, 2005).

Os princípios da unidade da Constituição - com prolação de decisão sempre atinente à sua sistematicidade -, da proporcionalidade e da dignidade da pessoa humana também são consectários utilizados a fim de proferir decisão conforme a essência dos valores constitucionais. Assim, "seguindo estes parâmetros, será possível delinear-se certa uniformidade das decisões envolvendo colisões de direitos fundamentais, em benefício da unidade e coerência do sistema; da segurança jurídica e da dignidade da pessoa humana" (BESSA, 2005, p. 18). Balizando tal decisão sempre pela ponderação, mas devendo sempre estar consciente de sua própria integração axiológica, os direitos fundamentais adquirem carga mais sólida e objetiva.

\section{Vida e intimidade (genética): um conflito passivel de ponderação na Reprodução Humana Assistida?}

Os contratos de Reprodução Humana Assistida trazem à baila a própria conceituação de pactos positivados na recente ordem econômica. Se, conforme aponta Padilha (2014), o abuso econômico é prática recorrente graças aos desníveis da distribuição econômica, em alguns contratos - como nos apontados no momento - o objetivo primeiro é, sim, o equilíbrio entre interesses e obtenção de finalidades em comum.

A este respeito, pontuam Fachin e Mendes (2012, p. 20) que "o contrato deixa de ter como escopo apenas tutelar os interesses egoísticos dos contratantes, 
devendo contar com um perfil instrumental de promoção da Dignidade da Pessoa Humana e da prosperidade social", sendo que a própria reprodução assistida desvela tal faceta de concatenação objetivando o máxime respeito aos direitos fundamentais e liberdade de contratação.

Insta memorar o fato de que os contratos redigidos sob a égide da novel ordem financeira apontada não são, contudo, alheios aos ditames constitucionais vigentes. Assim, “[...] nessa nova sociedade mundial que fez do contrato a sua norma jurídica mais relevante, cumpre ao intérprete e ao julgador realizar uma interpretação das normas de direito privado por meio de um diálogo com a Constituição do Brasil de 1988" (PADILHA, 2014, p. 108-9). A resposta do contrato à sua própria função social é a própria linha de condução do seu estudo, inseridos, por óbvio, os próprios instrumentos de Reprodução Humana Assistida.

Anteriormente à análise do conflito dos direitos fundamentais que se propõe o corrente estudo a explanar, urge a observância ao princípio da igualdade nas relações contratuais entre particulares, vez que “[...] cada pessoa possui a faculdade de escolher e fazer distinções de tratamento na celebração de contratos, na esfera privada, segundo as suas convicções, estilo de vida, posições ideológicas, etc." (PADILHA, 2014, p. 109). Nesta toada, a relação entre a equidade contratual e o funcionamento jusfundamental do próprio contrato sedimenta o funcionamento da negociação.

Um importante limite é fixado por Padilha, que se apercebe do fato de que a liberdade de contratar, cingida pela própria igualdade, limita-se pelo respeito à dignidade da pessoa humana, sendo este o maior instrumento de barreira para a análise interpretativa contratual. Dentro da reprodução assistida, onde a escolha do doador do material genético atende exclusivamente ao bel-prazer do receptor, não se poderia falar em discriminação ou redução da dignidade humana do doador, vez que insta existir "[...] uma justificativa relevante para a diferenciação [...]" (PADILHA, 2014, p. 111), sendo tal justificativa, neste caso, a própria natureza do contrato discutido, que almeja o livre planejamento familiar sem a interferência do Estado. ${ }^{3}$

Pela própria noção de reprodução assistida disciplinada por instrumento paritário - ou seja, com cláusulas livremente pactuadas e discutíveis - há de se

3 Questão passível de discussão, contudo, é acerca do fato dos contratos de Reprodução Humana Assistida se constituírem em verdadeiro contrato de adesão ou instrumento paritário. Ao se asseverar que se constituem como contratos de adesão, as cláusulas padronizadas e imutáveis para o doador levantam uma válida discussão acerca do desequilíbrio econômico e jurídico do contrato, merecendo tal questão aprofundamento em trabalho específico. Para que não se desborde do objetivo do corrente estudo, adotase a postura de tal contrato como tratativa paritária, vez que o hard case que ora se discute envolve apenas o conflito entre direitos fundamentais, não de mecanismos hermenêuticos de interpretação contratual. 
estabelecer o conflito que ora se propõe a estudar, qual seja, o embate entre vida e intimidade genética nos contratos de Reprodução Humana Assistida.

A definição de vida e intimidade, enquanto noções estanques de direito constitucional, pouco contribui para o objetivo ora proposto. A correlação de ambas, contudo, objetivando não só a concessão de vida, mas de vida digna, desvela as nuances ora almejadas. A questão paradoxal ora levantada é, portanto, a resposta ao conflito entre vida e intimidade num cenário contratual de reprodução assistida.

Sabendo-se que o indivíduo que doa seu material genético para posterior utilização por outrem é plenamente protegido em sua intimidade - ou seja, sabe que sua identidade não será revelada e nenhuma consequência patrimonial ou filial terá a prole gerada -, questiona-se o caso de eventual necessidade de revelação da identidade do doador a fim de possibilitar a doação de material biológico necessário ante o iminente risco de morte do indivíduo criado através de tais técnicas de reprodução assistida.

Apesar da ressalva de Padilha (2014, p. 115), que “[...] a aplicabilidade dos direitos fundamentais no âmbito do direito privado não deve ocorrer de modo indiscriminado, pois isto poderia trazer sérios riscos à autonomia privada, princípio este fundamental ao direito contratual”, nenhuma construção teórica é apta a afastar tal incidência jusfundamental no campo ora exposto, vez que se trata de bem fundamental de ordem eminentemente pública e transcendente: a vida humana.

Conforme exposto linhas atrás, a ausência de regulamentação legislativa da Reprodução Humana Assistida no Brasil dá azo a uma série de desdobramentos judiciais e contratuais e tal prática, com os respectivos questionamentos já apontados no momento específico. Contudo, o caso sob o qual ora se desdobra a corrente análise revela faceta verdadeiramente inédita no debate contratual erigido.

A resposta pode parecer óbvia e lógica - com a vida imediatamente posta em primeiro lugar em detrimento da intimidade genética -, mas as consequências de tal decisão afastam de plano a obviedade da pretensa resposta, visto que "[...] resta claro que a exclusão de cláusulas contratuais, sob a invocação dos direitos fundamentais, sem quaisquer parâmetros ou limites técnicos, é inequivocamente geradora de insegurança jurídica" (PADILHA, 2014, p. 116).

Grau (2001) expõe a causa mor da aludida (in)segurança jurídica: o liame objetivo ou subjetivo da relação contratual faz surgir uma justa situação de segurança e certeza entre as partes. 0 autor aponta, ainda, o fato de que os contratantes, ao crerem no fato de que a vinculação final Ihes será de considerável valia, fazem por crer, também, no cumprimento estrito do contrato, bem como em meios jurídicos para a execução da avença. 
A inesperada necessidade de revelação da identidade do doador demonstra insuperável insegurança jurídica contratual que poderia afastar futuros doadores, além de interferir na insegurança jurídica reflexa em outros contratos congêneres, vez que a tutela jurisdicional seria inegavelmente propensa a assistir o receptor. Há de se asseverar, contudo, que não se pretende, na esteia de Padilha (2014, p. 117), “[...] impor uma interpretação meramente econômica ou pecuniária da relação contratual, mas tão somente advertir que não se pode desconsiderar a tutela do crédito nos contratos", ainda que tal crédito seja de ordem eminentemente psicológica - a sondável certeza da condução contratual.

Há de se lembrar, contudo, que, em virtude da relação estabelecida pelo princípio da legalidade, ${ }^{4}$ o doador de material genético, ainda que venha a ter sua identidade revelada a fim de possibilitar sua localização para cessão de materiais biológicos para o receptor - como medula óssea, tecido de órgãos, sangue, etc. -, não será obrigado necessariamente a fornecê-los, sendo tal revelação de cunho de probabilidade para o receptor que se vê carente de tal item para a prole gestada.

Noutra banda, o direito à vida revela a suprema proteção do Estado em dúplice face: a não intervenção do ente supraindividual na livre condução vivencial e o acautelamento do acesso a todos os mecanismos possíveis - processuais ou não - à livre defesa e manutenção da vida, visto que, enquanto direito fundamental de primeira grandeza, a vida, acompanhada da liberdade, igualdade e dignidade, desvela verdadeiro objetivo do convívio em sociedade e sob o jugo do Estado.

Neste mesmo sentido, é cabível a compreensão de que “[...] tratando-se de direito fundamental à saúde e à vida, a aplicação dos direitos fundamentais nas relações jurídicas privadas deve ser imediata, sob pena de tornar-se inócuo o fim maior do contrato celebrado [...]. Nesse sentido, o julgador não deve se ater unicamente à declaração do direito [...]" (PADILHA, 2014, p. 126). É perceptível, desta feita, que o equacionamento da colisão entre os direitos fundamentais de vida e intimidade genética leva em consideração a) o afastamento da prevalência da vida enquanto resposta lógica com base na teoria da ponderação de Alexy; $b$ ) a delimitação da segurança jurídica enquanto instituto de reforço aos termos contratuais - ou seja, a certeza do doador na linearidade contratual com proteção de seu anonimato; e c) a concatenação dos próprios objetivos dos direitos fundamentais - a construção da vida com liberdade, igualdade e dignidade, em suma - como tentativa de dissolução do conflito jusfundamental.

4 Tal princípio se encontra insculpido no art. 5ํㅡ, Il da Constituição Federal, que versa: Art. 5o Todos são iguais perante a lei, sem distinção de qualquer natureza, garantindo-se aos brasileiros e aos estrangeiros residentes no País a inviolabilidade do direito à vida, à liberdade, à igualdade, à segurança e à propriedade, nos termos seguintes: [...] II - ninguém será obrigado a fazer ou deixar de fazer alguma coisa senão em virtude de lei. 
A suposta invocação de que um instrumento normativo sob o crivo do Congresso Nacional fosse ser apto a dar as respostas almejadas, em que pese carregar certa razão, não é de todo acertada. Mesmo se ulterior lei viesse a ditar a possibilidade de quebra do sigilo do doador sob o válido pretexto da efetividade do direito ao conhecimento da ascendência genética, questionável seria eventual vinculação legal do doador ao fornecimento de material fisiológico a fim de proteger a vida do indivíduo gerado a partir de sua doação, isto porque "[...] repudiam-se os modelos e as teorias fechadas, pois somente a análise do caso concreto é que poderá auxiliar na busca de uma melhor solução, em um trabalho de interpretação em que deverão concorrer vários outros elementos"5 (PADILHA, 2014, p. 134).

A nova tendência de interpretação contratual do Judiciário brasileiro é apontada por Padilha (2014) como voltada à persecução da dignidade humana, da boa-fé objetiva, dos valores não patrimoniais e da função social do contrato, trazendo à baila o fato de que o próprio deslocamento dos conflitos de direitos fundamentais somente exsurge numa abertura normativa que seja subjetiva o bastante para não ser enclausurada em mera relação obrigacional sedimentada num contrato.

A ponderação, enquanto técnica jurisprudencial e doutrinariamente adotada para a solução dos conflitos que ora se expõe, traz consigo ampla discricionariedade judicial - que não pode, sob pena de violação insuperável do próprio sistema constitucional-normativo, ser pautada em concepções pessoais do julgador - sendo que tal discricionariedade implica processo argumentativo, por meio do qual “[...] o julgador deve demonstrar de maneira racional, apresentando elementos de ordem jurídica [...] que a sua decisão é adequada à vontade constitucional. Eis o que se espera em um verdadeiro Estado Democrático de Direito" (PADILHA, 2014, p. 120).

A técnica ponderativa, como já exposta no item anterior e na redação de Barroso e Barcellos ([s.d]), limita-se em três momentos: a) a detecção das normas existentes no sistema e que reclamam aplicação no caso; b) o exame dos fatos e circunstâncias concretas; e c) a elaboração de decisão com concatenação da substancialidade das normas e repercussão dos fatos.

A questão da detecção das normas é de ordem eminentemente jusfundamental - vida e intimidade (genética) - com o próprio conteúdo discorrido em linhas atrás. A substancialidade de tais valores remonta ao próprio liame jurídico que embasa o conflito ora apontado, com vida e intimidade genética possuindo

5 Neste mesmo sentido, frisa-se uma eventual crise de constitucionalidade de eventual dispositivo que disponha no sentido apontado - de obrigatoriedade de fornecimento de material biológico posterior - com vistas no desvirtuamento da natureza contratual da Reprodução Humana Assistida e do próprio princípio da legalidade, com imediata ascensão da proteção à integridade física do doador. Percebe-se, em síntese, que um compartimento legislativo estanque não é resposta hábil ao conflito jusfundamental que ora se expõe. 
ampla aplicabilidade e fundamentos axiológicos. O exame dos fatos, por sua vez, reclama o embate - na qualidade de hard case - da prevalência de um ou outro direito fundamental no caso de indivíduo gerado por técnicas de Reprodução Humana Assistida carecer de material biológico do doador de sêmen/óvulos, infringindo o anonimato contratual a fim de preservar a própria existência. Por fim, a elaboração de tal decisão com base na ponderação de direitos é a fundação do corrente estudo.

Em que pese a segurança jurídica ser elemento primordial para o funcionamento do próprio Estado democrático, urge observar que o livre acesso do indivíduo a todos os meios possiveis para a defesa da própria vida também é prerrogativa estatal com fulcro jusnaturalista e atualmente positivada no rol de garantias fundamentais. A situação de aparente - e verdadeira - complexidade encontra desdobramentos não só na própria vida que se quer defender, mas nas nuances de dignidade, legalidade e autonomia privada. Se de um lado se tem a necessidade de defender a segurança jurídica contratual sob o risco de se mitigar o próprio funcionamento do Estado, noutra banda se vê o mais singelo e imutável objetivo estatal: a defesa da vida humana.

Ao se deter nos instrumentos de Direito Comparado levados a cabo, vê-se a imensa opção legislativa alienígena pela divulgação do doador de material genético a fim de assegurar o conhecimento do indivíduo de quem lhe ajudou a criar - ainda que apenas biologicamente. Mitigar tal hipótese parece ser improvável, quiçá impossível, ante a flagrante opção pelos direitos fundamentais do terceiro alheio à relação contratual; o filho. Vencer a questão acerca da divulgação ou não do nome, ainda que seja tema de inegável aporte no estudo que ora se conduz, pouco contribui quanto à crise de legalidade na obrigatoriedade de fornecimento de material biológico pelo doador.

Imbuir mecanismo coercitivo por vias jurisdicionais a fim de determinar a extração de medula óssea, sangue ou qualquer outro tecido ou fluido corporal do doador viola não só o princípio da legalidade e da dignidade da pessoa humana, mas também desvirtua a natureza contratual dos instrumentos de reprodução assistida, vez que não se trata tal avença de constituição de vínculo familiar entre mero doador de material genético e o indivíduo produto direto das técnicas conceptivas artificiais. Há de se expor que o livre planejamento familiar, cuida-se, de fato, de direito/obrigação pertencente única e exclusivamente aos receptores de tal material, sendo ilógica a tentativa de envolver o doador em tal liame subjetivo.

Se, na hipótese, tem-se a proteção à vida em todas as suas formas como objetivo inafastável da ordem republicana constitucional, vê-se que é possível a divulgação da identidade do doador de material genético a fim de conceder tentativa de fornecimento de ulterior material biológico, mas impossível é, sob a égide da 
Constituição garantista em que se vive, a coerção judicial do receptor para que forneça, por exemplo, medula óssea a indivíduo submetido a tratamento oncológico e que seja fruto de seu sêmen ou óvulo, ou pedaço de tecido ou órgão para este mesmo sujeito. A ponderação, desta forma, embora sirva para diminuir a aplicabilidade de um ou outro direito, não se presta a extirpá-lo do ordenamento jurídico, ou negar-lhe vigência geral, mas apenas a forçar inevitável relação de coexistência em casos que clamam pela aplicabilidade una.

Ao final, percebe-se que, ao evitar a formação de vínculo familiar entre o doador e o indivíduo gerado por seu material genético, as técnicas de Reprodução Humana Assistida, ainda que fragilmente disciplinadas por resolução do Conselho Federal de Medicina, desvelam sua face eminentemente contratual a fim de garantir a existência digna e feliz de família ou sujeito incapaz de gerar um filho sozinho, seja por razões meramente fisiológicas ou afetivas. Ao garantir o livre planejamento familiar, o texto constitucional e a natureza contratual da reprodução assistida vinculam o terceiro doador em mera relação de consumo - um objeto respeitado em sua dignidade, mas que ainda assim serve aos interesses eudemonistas de outrem.

O ulterior surgimento de moléstia que force a aproximação entre o produto das técnicas reprodutivas e um de seus realizadores não tem o condão de afastar tal natureza contratual e constitucionalmente construída, ainda que possa mitigála na eventual revelação da identidade do doador, como também poderia sob o simples crivo do direito ao conhecimento da ascendência familiar - neste caso, meramente genética - sendo que a prevalência da integridade física do doador não revela faceta constitucional fria ou inconsciente de seus dependentes, mas verdadeira barreira jusfundamental e criticamente construída, objetivo elementar da própria ordem jurídica existente.

\section{Considerações finais}

O processo de Reprodução Humana Assistida exsurge como paradoxo pósmoderno de contornos técnico-científicos. A possibilidade de controle sobre os próprios mecanismos de reprodução acalenta mais do que um sonho da humanidade, mas também traz consigo uma série de vetores bioéticos dos quais o Direito não pode se eximir de posicionamentos. É dentro de tal quadro de complexidade social que os direitos fundamentais - e sua necessidade de equilíbrio - emergem como respostas lógicas.

A teoria da horizontalidade dos direitos fundamentais, que, como dito anteriormente, adquire enorme relevo após o contexto da Segunda Guerra Mundial, 
demonstra a eminente necessidade de concatenação de objetivos comuns de relações privadas dentro do complexo cenário do Direito Público. O respeito - que aqui quase beira a observância obrigatória conferida pelo critério da aplicabilidade (i)mediata dos direitos fundamentais - às garantias constitucionais elementares traz à tona uma série de questionamentos sobre a validade e a ponderação de tais relações jurídicas.

O respeito ao anonimato, tanto do doador de material genético quanto de seu receptor, enquanto base para o funcionamento de tal relação essencialmente contratual, agora adquire contornos de paradoxo jusfundamental. A eventual necessidade de revelação da identidade de um ou de ambos os polos de tal relação jurídico-contratual para que outro direito fundamental seja respeitado traz à tona a cartela de princípios constitucionais sistemáticos que orientam tais situações conflituosas e paradoxais. A ponderação, aqui, mais uma vez deve ser detida e em consonância com a complexidade do caso concreto apresentado.

Não há, por fim, prevalência deste ou daquele direito fundamental dentro da ordem jurídica, mas, sim, a constante lembrança da impossibilidade de absolutismos em matéria de liberdades intersubjetivas, pois o próprio quadro da Reprodução Humana Assistida emerge dentro da relativização de várias destas mesmas liberdades. O que urge, então, é a rememoração de que a ordem constitucional não prega valores imutáveis e intangiveis, mas a concatenação e o justo equilíbrio, aqui sempre analisados dentro do fulcro da ponderação.

\title{
The right to life against the right of privacy in genetic material donation contracts
}

\begin{abstract}
The present article aims to analyze the right to life against the right to privacy, especially in its species linked to human genetics around the genetic material donation contracts that exist in the Assisted Human Reproduction practices. For such approach, the current study looks into the fundamental rights' collision problematic, establishing its meaning and solution practices, appealing mainly to the ponderation technique created by Robert Alexy. After the analysis of jusfundamental conflict, it stipulates a possible solution for the pointed conflict, recurring to the resolution techniques pointed until then, determining the prevalence of right to life, if respected a series of conduction paradigms in such case. The research here conducted is eminently bibliographical, with the influence of precedents from Constitutional Courts of countries like Germany and Brazil, besides to grounds in the classical theory of fundamental rights that exists in continental Law.
\end{abstract}

Keywords: Fundamental rights collision. Right to life. Right to privacy. Assisted Human Reproduction. Genetic material donation.

Contents: Introduction - $\mathbf{1}$ The issue of fundamental rights impact - $\mathbf{2}$ Theories of conflict resolution between fundamental rights: the reflection in Alexy $\mathbf{-} \mathbf{3}$ Life and intimacy (genetic): a conflict subject to reflection in assisted human reproduction? - 4 Final considerations - References 


\section{Referências}

ALEXY, R. Teoria dos Direitos Fundamentais. São Paulo: Malheiros, 2008.

ARCHANJO, D. R. O princípio da proporcionalidade na solução de colisões de direitos fundamentais. In: Espaço Jurídico, Joaçaba, v. 9, n. 2, p. 151-168, jul./dez. 2008.

AZEVEDO, E. P. de; GAMBIATTI, D. A. Estudos sobre concorrência e colisões de direitos fundamentais. Unoesc \& Ciência - ACSA, Joaçaba, v. 3, n. 1, p. 79-88, jan./jun. 2012.

BARROSO, L. R.; BARCELLOS, A. P. de. O começo da história: a nova interpretação constitucional e o papel dos princípios no direito brasileiro. [s.d]. Disponível em: <http:// www.camara.rj.gov.br/setores/proc/revistaproc/revproc2003/arti_histdirbras.pdf $>$. Acesso em: 30 jun. 2015.

BESSA, L. S. Colisões de Direitos Fundamentais: propostas de solução. In: Anais do XIV CONPEDI, Cuiabá, 2005, p. 1-19.

BRIANCINI, V. Colisão de Direitos Fundamentais e Aplicação do Princípio da Proporcionalidade nas Relações de Trabalho. Dissertação de mestrado. Universidade de Caxias do Sul: Caxias do Sul, 2007. $96 f$.

CAMPOS, H. N. Princípio da Proporcionalidade: a ponderação dos direitos fundamentais. In: Cadernos de Pós-Graduação em Direito Político e Econômico, v. 4, n. 1, p. 23-32, 2004.

DIMOULIS, D.; MARTINS, L. Teoria Geral dos Direitos Fundamentais. 5. ed. São Paulo: Atlas, 2014.

FACHIN, Z.; MENDES, L. F. Abertura sistêmica do direito civil contratual como promoção da democracia. In: Scientia luris, Londrina, v. 16, n. 1, p. 9-24, jul. 2012.

GORZONI, P. Entre o princípio e a regra. In: Novos Estudos - CEBRAP, São Paulo, n. 85, p. 273-279, 2009.

GRAU, E. R. Um novo paradigma dos contratos? In: Revista FGV Direito Rio, Rio de Janeiro, 2001.

MASTRODI, J. Ponderação de direitos e proporcionalidade de decisões judiciais. In: Revista Direito GV, São Paulo, n. 10, v. 2, p. 577-595, jul./dez. 2014.

PADILHA, E. A eficácia dos direitos fundamentais nas relações contratuais entre particulares. Porto Alegre: Núria Fabris, 2014.

RECKZIEGEL, J. A responsabilidade civil do Estado frente às limitações ao direito de propriedade nas áreas de preservação permanente às margens dos rios urbanos. Dissertação de mestrado. Universidade de Caxias do Sul: Caxias do Sul, 2006. 138f.

; FREITAS, R. S. de. Limites e abusos de interpretação do Supremo Tribunal Federal no caso ADPF 54 (aborto de anencéfalos): análise crítica a partir de Habermas e Streck. In: Pensar, Fortaleza, v. 19, n. 3, p. 693-720, set./dez. 2014. 
SALOMÃO, K. R.; MARQUES, D. M. Dificuldades Contramajoritárias: Critérios Legitimadores da Jurisdição Constitucional. In: E-Civitas, Belo Horizonte, v. VII, n. 2, dez. 2014. Disponível em: <http://revistas.unibh.br/index.php/dcjpg/article/view/ 1322/758>. Acesso em: 02 jun. 2015.

SARLET, I. W. A eficácia dos direitos fundamentais. 10. ed. Porto Alegre: Livraria do Advogado, 2009.

STEINMETZ, W. Colisão de direitos fundamentais e princípio da proporcionalidade. Porto Alegre: Livraria do Advogado, 2001.

Recebido em: 23.11.2015

Pareceres: 06.06.2016 e 08.07.2016

Aprovado em: 12.07.2016

Informação bibliográfica deste texto, conforme a NBR 6023:2002 da Associação Brasileira de Normas Técnicas (ABNT):

RECKZIEGEL, Janaína; DUARTE, Jhonatan Felipe Laurindo Gomes. O direito à vida versus o direito à privacidade nos contratos de doação de material genético. Direitos Fundamentais \& Justiça, Belo Horizonte, ano 10, n. 34, p. 203-221, jan./jun. 2016. 